\title{
A new soft-shelled trionychid turtle of the genus Khunnuchelys from the Upper Cretaceous Bostobe Formation of Kazakhstan
}

Igor G. Danilov, Natasha S. Vitek, Alexander O. Averianov, and Vadim N. Glinskiy

Acta Palaeontologica Polonica 60 (1), 2015: 155-161 doi: http://dx.doi.org/10.4202/app.2013.0045

Previously unpublished trionychid turtle material from the Upper Cretaceous

(Santonian-lower Campanian) Bostobe Formation from the Baybishe and Baykhozha

localities in Kazakhstan is described. The material represents a new species of Khunnuchelys

, a large, skull-based clade of Cretaceous Asian trionychids. Concordant with other partial

skulls and fragmentary specimens described previously, Khunnuchelys lophorhothon sp. nov. has

the unusual features of a beaklike maxilla and a vaulted, expanded triturating surface. In

addition, the specimens reveal novel features including a constricted skull roof. Although

estimates of the length of the carapace differ depending on estimation method, the skull

belonged to a turtle of comparable size to the shell-based species "Trionyx" kansaiensis from the same

formation. It is likely that $K$. lophorhothon and "T." kansaiensis are synonymous, but this can be proved only by a find of associated skull and shell material.

Key words: Testudines, Trionychidae, Trionychia, Khunnuchelys lophorhothon, Cretaceous, Kazakhstan.

Igor G. Danilov [igordanilov72@gmail.com] and Alexander O. Averianov [dzharakuduk@mail.ru ], Zoological Institute of the Russian Academy of Sciences, Universitetskaya Emb. 1, 199034, St. Petersburg, Russia; Natasha S. Vitek [nsvitek@utexas.edu ], Jackson School of Geosciences, The University of Texas at Austin, Austin,

TX, USA; Vadim N. Glinskiy [vadim.glinskiy@gmail.com], Department of Paleontology, Geological Faculty, St. Petersburg State University, Universitetskaya Emb. 7/9, 199034, St. Petersburg, Russia.

This is an open-access article distributed under the terms of the Creative Commons Attribution License (for details please see creativecommons.org), which permits unrestricted use, distribution, and reproduction in any medium, provided the original author and source are credited. 
For Full text $(1,406.5 \mathrm{kB})$ 